\title{
Overview of Herbal Therapy with Leave of Gynura procumbens (Lour.) Merr
}

\author{
Kris Herawan Timotius ${ }^{1,2, *}$, Ika Rahayu ${ }^{1,2}$ \\ 'Department of Biochemistry, Faculty of Medicine, Universitas Kristen Krida Wacana (UKRIDA), West Jakarta, INDONESIA. \\ ${ }^{2}$ Research Center for Jamu and Herbal Medicine (JaHe), Universitas Kristen Krida Wacana (UKRIDA), West Jakarta, INDONESIA.
}

\begin{abstract}
Plants are important source of traditional medicine that can be used to aid many type of illness. Gynura procumbens is one of the plants that are often used by Indonesian people as traditional medicine. Gynura procumbens exhibits antibacterial, anticancer, anti-hyperglycemic, antihypertensive, anti-inflammatory, antioxidant, cardioprotective, fertility enhancement, organ protective activity. This review aims to provide an overview on the relatedness of the identified bioactive compounds with the reported biological activities of Gynura procumbens leave and on the herbal therapy with leave of Gynura procumbens. Literature search is carried out with the help of two searching engines: PubMed and Science Direct. The searching was carried out with keyword: Gynura procumbens. From PubMed and Science Direct, 42 and 94 results were obtained respectively. There were 45 full text articles that meet systematic review criteria. The relevant information is compiled to illustrate that leave of Gynura procumbens is a potential natural source of compounds with various pharmacological actions. Polar, semi and nonpolar solvent can be used to extract the bioactive compounds from the leave of Gynura procumbens. The identified bioactive
\end{abstract}

compounds belong to phenolic, flavonoid, coumaric acids, essential oils, carbohydrates and proteins. Most of the extracts show potent antioxidative activity. The bioactivities of the leave extract are associated with many diseases, such as diabetes, hypertension, cancer, obesity, etc. The herbal therapy with leave of Gynura procumbens can be appropriately applied in oral administration and topical application. Leave of Gynura procumbens is good resource for oral or topical herbal medicine/ingredient.

Key words: Bioactive compound, Bioactivity, Gynura procumbens, Sambung nyawa, Antioxidant activity.

Correspondence

Prof. Dr. Kris Herawan Timotius

Department of Biochemistry, Faculty of Medicine, Universitas Kristen Krida Wacana (UKRIDA), West Jakarta, INDONESIA.

Phone: +62-21 5666952

Email: kh_timotius@ukrida.ac.id

DOI: 10.5530/jyp.2020.12.61

\section{INTRODUCTION}

Gynura procumbens (Lour.) Merr. (Family Asteraceae/Compositae) which is known as "Sambung nyawa", is a medicinal plant commonly found in tropical Asia countries. The leave is traditionally used for the treatment of cancer, diabetes mellitus, fertility enhancement, high cholesterol level, hypertension, inflammation, oxidative stress, rheumatism. It is also important for organ protections (cardioprotection, hepatoprotection, skin protection, kidney protection). ${ }^{1,2}$

Compared with other plant parts (stem and root), leave is more easy to get and available all the time. By taking the leave, the plant is not disturbed so much and able to continue its growth normally. Traditional uses of $G$. procumbens (GP) leave show that it possesses high therapeutic potential for treatment of various diseases. Pharmacological studies that targeting the leave are necessary to validate and provide scientific evidence for the traditional claims of its efficacy.

This review aims to evaluate, from the previous reports, the relatedness of the identified bioactive compounds with studied bioactivities of GP leave and then to form knowledge on the application of the herbal therapy with GP leave. For this review, information was compiled to illustrate that GP leave is a potential natural source of bioactive compounds with various pharmacological actions. Information was searched from PubMed, Science Direct and Google Scholar, with Gynura procumbens as the main keyword. And then the results were screened according to the presence of the bioactive compounds and their bioactivities Even, there are several reviews on GP already published, ${ }^{1}$ this review is made with different approach. The focus of this review is on the relatedness of the bioactive compounds and bioactivities and the applicative herbal therapy of the GP leave.

\section{METHODS}

PubMed and Science Direct were used as searching engines in this study. The searching was carried out up to March 30 $30^{\text {th }}, 2020$ with keyword: Gyanura procumbens. From PubMed and Science Direct, 42 and 94 results were obtained respectively. Inclusion criteria for this study were the relevant articles related to Gyanura procumbens and studies that published in English. 91 irrelevant titles were excluded due to duplication and outside of the scope. 45 full text articles were met the systematic review criteria.

\section{BIOACTIVE COMPOUNDS FROM THE LEAVES OF GYANURA PROCUMBENS}

\section{Phenolic and flavonoid compounds}

The composition and the total content of phenolic and flavonoids in the GP-leave extract depend on the solvent used to extract. Aqueous, methanol, ethanol, n-butanol, ethyl acetate, contain different kind and amount of phenolic and flavonoid compounds (Table 1). ${ }^{3,4}$

\section{a. Chlorogenic acid}

GP leave contains chlorogenic acid dimer that has potent antioxidant activity. It can be good digested and metabolized. It can be found as

This is an open access article distributed under the terms of the Creative Commons Attribution-NonCommercial-ShareAlike 4.0 License, which allows others to remix, tweak, and build upon the work non-commercially, as long as the author is credited and the new creations are licensed under the identical terms. 
the main active ingredients (13.6\%) in the $60 \%$ ethanol-eluted fraction. Therefore, GP-leave is reasonable considered as a health care vegetable and a functional food ingredient for antioxidant enhancement and ethanol-induced liver injury treatment. ${ }^{5,6}$

\section{b. Cynarine, isochlorogenic acids $A$ and isochlorogenic acids $C$}

Ethyl acetate extract of GP leave contains three main polyphenols, cynarine, isochlorogenic acids $\mathrm{A}$ and isochlorogenic acids C. All compounds have excellent anti-oxidizing and anti-inflammatory activities. $^{7}$

\section{c. Caffeoylquinic acids}

From ethanol extract of GP leaves, two fractions are obtained, caffeoylquinic rich and chlorogenic acid (one of the major caffeoylquinic acids) fractions. Both have potent antihyperlipidemic effects, with significant reductions in total cholesterol, triglycerides, low-density lipoprotein-cholesterol, very low-density lipoprotein-cholesterol, atherogenic index and coronary risk index. But only caffeoylquinic rich fraction increases the high-density lipoprotein cholesterol. The caffeoylquinic rich fraction shows better effect than chlorogenic acid alone The findings suggest that the di-caffeoylquinic acids may also in part be responsible for the potent antihyperlipidemic and shows the highest antioxidant activity. The enriched the caffeoylquinic acids fraction can better improve antihyperlipidemic and antioxidant capacities than the ethanol extract. Therefore, fraction that rich caffeoylquinic has potential for development into phytopharmaceuticals as adjunct therapy for management of hyperlipidaemia. ${ }^{8}$

\section{d. Quercetin}

GP ethanol leave extract contains quercetin, around $18 \%$. This GP leave extract when combined extract with Azadirachta indica, has better hypoglycaemic effect than the single treatment of $A$. indica or GP. Combination of both extracts is potential as a blood glucose-lowering agent. $^{9}$

\section{e. $p$-Caumaric acids}

Three groups of phenolic compound are found in ethanol extract, hydroxybenzoic acids, hydrocinnamic acids and flavonoids. Caumarins are lactones of cis-O-hydroxycinnamic acid derivates that plant origin and exist in the free form or as glycosides. Two main dominant phenolic acids are p-caumaric acid and kaempferol. Fractionation with ethyl acetate results a rich p-coumaric acid fraction. Its concentration in ethyl acetate fraction is three times higher than the ethanol extract. Fractionation with chloroform and n-butanol do not enrich the p-caumarin content. ${ }^{10}$

Several flavonol glycosides are detected in n-butanol fraction, kaempferol 3-O-glucoside, kaempferia 3-O-rhamnosyl $(1 \rightarrow 6)$ glycoside, quercetin 3-O-rhamnosyl $(1 \rightarrow 2)$ galactoside, quercetin 3-O-rhanosyl $(1 \rightarrow 6)$ glucoside. ${ }^{11}$ Two glycosides are detected in methanol extract, ethyl acetate and n-butanol fraction, kaempferol-3-O-rutinoside and astragalin. Both are found at highest percentage in ethyl acetate. ${ }^{12}$

\section{f. Essential oils}

The active ingredients in the essential oils from GP are alpha-pinene, 3 -carene and limonene that underlying the anti-inflammatory and antinociceptive effects in vivo and in vitro. These three active ingredients have potent pharmacological effects on COX-2 overexpression and LPSinduced migration of macrophages, which is responsible for the antiinflammatory effect. But, only 3 -carene has an antinociceptive effect. ${ }^{13}$

\section{g. Steroid}

There is an evidence of the presence of steroid in GP leave that might be one class of anti-inflammatory and antiviral compounds. ${ }^{14}$ Methanol fraction contains a mixture of $\beta$-sitosterol and stigmasterol and sterol glycosides containing 3-O- $\beta$-D-glucopyranosyl $\beta$-sitosterol and 3-O- $\beta$ D-glucopyranosylstigmasterol and 1, 2-bis-dodecanoyl-3- alpha -D-glucopyranosyl-sn-glycerol. ${ }^{15,16}$

\section{h. Carbohydrates}

Fractionations of GP leave (20\%, 40\%, $60 \%$ and $80 \%$ ethanol) result four polysaccharides (GPP-20, GPP-40, GPP-60 and GPP-80), successively. They belong to heteropolysaccharides that consist of arabinose, galactose, glucose, xylose and galacturonic acid. Apart from these monosaccharides, their structures contain uronic acids and proteins. GPP-20, GPP-40 and GPP-80 exhibits better antioxidant activities than GPP-60. ${ }^{17}$

\section{i. Proteins}

A proteomic study of the GP leave shows abundantly expressed proteins. ${ }^{2}$ Several leave proteins are identified and considered as valuable plant defence proteins, especially miraculin and thaumatin-like proteins. Miraculin is a taste-masking agent with high commercial value that made up approximately $0.1 \%$ of the total protein extracted. ${ }^{2}$ Thaumatin like proteins are found to inhibit the growth of a breast cancer cell line. ${ }^{18}$ Glycoconjugated or peptidal substances are also found. The presence of glycoconjugates and peptides are supposed to have hypotensive effect related with its capacity to exhibit an inhibitory effect on angiotensinconverting enzyme (ACE). ${ }^{19}$

\section{PHARMACOLOGICAL ACTIVITIES}

\section{a. Antioxidative activities}

GP leave have antioxidative activities. Its polar and nonpolar extract contain polyphenols that determine the excellent antioxidizing and antiinflammatory activities. ${ }^{7,20}$

\section{b. Anti-diabetic}

The aqueous extract of GP leave has hypoglycaemic effect that significantly decreases blood glucose levels. GP water extract exerted its hypoglycaemic effect or antihyperglycaemic activity by

- $\quad$ promoting glucose uptake by muscles ${ }^{21}$

- having biguanide-like activity ${ }^{22}$

- having high content of phenols and flavonoids ${ }^{3}$

- having a metformin-like mechanism ${ }^{4}$

- Improving insulin sensitivity and inhibit gluconeogenesis in the liver. $^{23}$

- inhibiting a-glucosidase and a-amylase inhibitory effects (carbohydrate digesting enzymes). ${ }^{24}$

\section{c. Antihypertensive effect}

Aqueous extracts of GP can be orally administered to determine an antihypertensive effect. Oral administration GP leave extract and/or fractions result in

lower blood pressure, ${ }^{25}$

- lower serum lactate dehydrogenase and creatine phosphate kinase,

- inhibition of the angiotensin-converting enzymatic activity, ${ }^{19,26,27}$

- vasodilatation/vasorelaxant activity, a positive inotropic activity, by blocking calcium channels and opening of potassium channels. ${ }^{26,28,29}$ 


\section{d. Anticancer}

The GP leave has been traditionally used as anticancer. The antitumor effect of GP-leave is confirmed by the facts that

- Its ethanol extract is able to induce apoptosis (cytotoxic activity) and suppress proliferation (antiproliferative) and metastasis. ${ }^{30-32}$

- Its defence proteins inhibit the growth of a breast cancer, reduce the mRNA expressions of proliferation markers and the expression of invasion marker. ${ }^{18}$

- Its methanol extract has cytotoxic effects either under hypoxic or normoxic conditions. ${ }^{33}$

\section{e. Profertility effect}

GP aqueous extract is applicable in treating male infertility, possibly through the up regulation of proteins related to sperm maturation and sperm-egg interaction. These proteins involve in sperm maturation, sperm capacitation and sperm-egg interaction. GP leave treatment is able to restore the fertility at molecular protein level. ${ }^{34}$

\section{f. Antibacterial}

In the feeding experiment with chicken, it is observed that dietary feed of GP leave reduces the excreta total anaerobic bacteria, Clostridium ssp. and Escherichia coli. ${ }^{35}$ Another experiment with weanling pigs show that

Table 1: Bioactive and bioactivity of leave extracts of Gynura procumbens.

\begin{tabular}{|c|c|c|}
\hline Extract & Bioactive & Bioactivity \\
\hline \multicolumn{3}{|l|}{ Single-solvent extracts } \\
\hline Health care vegetable & Chlorogenic acid dimer & Antioxidant activity ${ }^{5}$ \\
\hline \multirow[t]{2}{*}{ Aqueous } & & Hypoglycaemic effect ${ }^{21}$ \\
\hline & & Hepato protective effect ${ }^{45}$ \\
\hline \multirow[t]{2}{*}{ "essential oils" } & alpha-pinene, 3 -carene, limonene ${ }^{13}$ & Anti-inflammatory ${ }^{13}$ \\
\hline & & Anti-nociceptive effects ${ }^{13}$ \\
\hline Methanol & & Hepatoprotetive effect ${ }^{44}$ \\
\hline $\begin{array}{c}\text { Methanol } \rightarrow \text { Ethyl Acetate } \\
\text { Methanol } \rightarrow \text { Butanol }\end{array}$ & $\begin{array}{l}\text { Kaempferol-3-Orutinoside and } \\
\text { astragalin }^{41}\end{array}$ & \\
\hline \multirow[t]{5}{*}{ Ethanol } & steroids $^{14}$ & Anticancer activity 30,31 \\
\hline & & Hepato protective effect ${ }^{6,45}$ \\
\hline & & Inflammation ${ }^{6,30,45}$ \\
\hline & & Rheumatism $^{30,31}$ \\
\hline & & Antivirus ${ }^{14,30}$ \\
\hline \multirow[t]{2}{*}{ Ethanol } & Caffeoylquinic rich and chlorogenic & Antioxidant $^{7}$ \\
\hline & $\operatorname{acid}^{8}$ & Anti-hyperlipidaemia effects ${ }^{8}$ \\
\hline Ethanol & Quercetin ${ }^{9}$ & Hypoglycaemic effect ${ }^{9}$ \\
\hline $\begin{array}{l}\text { Ethanol extract Fractionation with ethyl } \\
\text { acetate results a rich p-coumaric acid }\end{array}$ & p-caumaric acid, kaempferol ${ }^{10}$ & \\
\hline \multirow[t]{2}{*}{ n-Butanol fraction } & $\begin{array}{c}\text { kaempferol 3-O-glucoside, } \\
\text { kaempferia 3-O-rhamnosyl }(1 \rightarrow 6) \\
\text { glycoside, }\end{array}$ & \\
\hline & $\begin{array}{l}\text { quercetin 3-O-rhamnosyl }(1 \rightarrow 2) \\
\text { galactoside, quercetin 3-O-rhanosyl } \\
(1 \rightarrow 6) \text { glucoside }^{11}\end{array}$ & \\
\hline \multirow[t]{2}{*}{ Ethyl Acetate } & cynarine, isochlorogenic acids A & Antioxidizing $^{7}$ \\
\hline & isochlorogenic acids $\mathrm{C}^{7}$ & Anti-inflammatory ${ }^{7}$ \\
\hline \multirow[t]{2}{*}{ Petroleum ether } & & Antioxidant activity \\
\hline & & Vasorelaxant effect ${ }^{39}$ \\
\hline \multicolumn{3}{|l|}{ Serial extract/fraction } \\
\hline Ethanol $\rightarrow$ Butanol & Phenolic and flavonoids ${ }^{3}$ & Anti-hyperglycaemic activity ${ }^{3}$ \\
\hline $\begin{array}{l}\text { Ethanol } \rightarrow \text { EthylAcetate } \rightarrow \text { hexane or } \\
\text { toluene }\end{array}$ & Steroid & Anti-inflammatory activity ${ }^{14}$ \\
\hline Ethanol $\rightarrow$ Water & & No anti-inflammatory activity ${ }^{14}$ \\
\hline \multirow{2}{*}{$\begin{array}{c}\text { Petroleum Eter } \rightarrow \text { Ethyl Acetate } \rightarrow \text { Butanol } \\
\text { Methanol fraction }\end{array}$} & Chlorogenic & Hepato protective $^{6}$ \\
\hline & $\begin{array}{l}\text { Beta -sitosterol, stigmasterol beta } \\
\text {-sitosteryl and stigmasterylglucosides }\end{array}$ & Antivirus compounds $\mathrm{s}^{15}$ \\
\hline Ethanol fraction & heteropolysaccharides & Antioxidant activities ${ }^{17}$ \\
\hline \multirow[t]{2}{*}{ Active protein fraction } & Miraculin, thaumatin-like proteins & Anticancer ${ }^{18}$ \\
\hline & $\begin{array}{c}\text { Glycoconjugated or peptidal } \\
\text { substances }^{2}\end{array}$ & Hypotensive effect ${ }^{19}$ \\
\hline
\end{tabular}


fermented medicinal plants (polyherbal formulation) that contain GP leave as one of the ingredient, is able to enhance growth performance and nutrient digestibility and decreasing faecal noxious emission and early diarrhoea score. This polyherbal formulation is good as an alternative to antibiotics. ${ }^{36}$

\section{g. Antivirus (Antiherpetic)}

The ethanol extract of GP-leave shows virucidal and antireplicative actions against herpes simplex virus. Fractions that a mixture of dicaffeolquinic acids, beta -sitosterol and stigmasterol, beta -sitosteryl and stigmasterylglucosides and 1, 2-bis-dodecanoyl-3- alpha -D-glucopyranosyl-sn-glycerol show antiherpetic or virucidal and antireplicative actions. ${ }^{15}$

\section{h. Antiinflamation}

Essential Oils may serve as a promising potent external therapeutic agent for the treatment of chronic pain. With its active ingredients (alphapinene, 3-carene and limonene), GP essential oils inhibit the nociceptive stimulus-induced inflammatory infiltrates and COX-2 overexpression, which are responsible for the anti-inflammatory effect. Only 3-carene exhibits an antinociceptive effect. ${ }^{13}$ While the water extract did not show any anti-inflammatory activity, the hexane and toluene fractions from the crude ethanol extract of GP leave show anti-inflammatory activity. The hexane and toluene fractions show significant inhibition. ${ }^{14}$

\section{i. Anti-hyperlipidaemia effects}

Ethanol extract of GP leave possesses anti-hyperlipidaemia effects. The caffeoylquinic acids rich fractions from the ethanol extract has anti-hyperlipidaemia with significant reductions in total cholesterol, triglycerides, low-density lipoprotein-cholesterol, very low-density lipoprotein-cholesterol, atherogenic index and coronary risk index. The di-caffeoylquinic acids are responsible for the potent antihyperlipidaemia effect. ${ }^{8}$

\section{j. Organ protection}

The protective effect of GP leave against damage of body tissues and organs has also been evaluated. GP leave has significant potential as an organ protective agent; mainly due to its antioxidative properties which exert a regulatory effect at the level of gene expression. ${ }^{1}$ The protective effect of GP leave should be explored in the future.

\section{GP leave is found to exert}

- a gastro protective effect as the oral administration of ethanol $\operatorname{extract}^{37,38}$

- a hepato protective effect ${ }^{6,1}$

- a cardiovascular effect ${ }^{39}$

- $\quad$ a skin photo aging effect ${ }^{38}$

- a kidney protection effect ${ }^{1,40}$

\section{k. Safety and Toxicity}

The safety or toxicological information is not much available. Administration of the methanol extract from GP leave does not produce mortality or significant changes in the general behaviour, body weight, or organ gross appearance of experiment rats. ${ }^{41}$ It is not yet confirmed with the use of other solvents. But aqueous extract is considered as safe, so far there is no complaint or report from the traditional use of the aqueous extract. GP leaves have a no-observed-adverse-effect-level (NOAEL) corresponding to the high content of phenols and flavonoids. ${ }^{3}$ GP plant seems to have bio remedial potential. This plant is able to do bioaccumulation of heavy metals in the soil, such as cadmium $(\mathrm{Cd})$ and copper $(\mathrm{Cu})$. Production of total phenolic, flavonoid and saponin is observed to be reduced under combined $\mathrm{Cd}$ and $\mathrm{Cu}$ treatment. The curent experiments show that the medicinal properties of GP are reduced by cadmium and copper contamination. These results indicate that exposure of GP to $\mathrm{Cd}$ and $\mathrm{Cu}$ contaminated soil may potentially harm consumers due to bioaccumulation of metals and reduced efficacy of the herbal product. ${ }^{42}$

\section{RELATIONSHIP BETWEEN BIOACTIVE COMPOUNDS AND BIOACTIVITIES}

The efficacy of the herbal medicine depends on the composition and amount of bioactive compounds available in the herbal materials. Several factors determine the composition and amount of the bioactive compounds, mainly the extraction procedure and the fractionation. Phytoextracts of GP-leave can be obtained by using various solvents, such as water, methanol, ethanol, ethyl acetate and petroleum ether. Polarity of the solvent determine the constituent composition of the extract. To get the preparation which rich in certain compounds, a fractionation of chromatographically separation should be done. A partially purified fraction can be obtained so that a more specific bioactivity can be obtained.

As written above, bioactive compounds of the GP leave can be divided into five groups, namely phenolic and flavonoid compounds, essential oils, steroid, leave carbohydrates and leave protein. Bioactivities of the GP leave are associated with several diseases that can be categorized into two groups, based on the herbal drug delivery methods, the oral administration and topical or external therapeutic application. The first group of disease that need oral administration of GP herbal medicine is diabetes, hypertension, anti-cancer, gastrointestinal infectious disorder, including organ protective effect except skin. The second group of diseases that need topical application is inflammation, rheumatism, viral (herpes) disease, including skin protective effect.

Bioactive compounds that effective for the remedying the diseases in the first group is characterized with the richness in phenolic and flavonoid compounds, carbohydrate and leave proteins. The antioxidant activities of the bioactive compounds are usually very potent. The bioactive compounds of the second group are characterized by sterol and essential oil. The first group is usually being treated with crude extracts. For the second group, except essential oil, special partial purification (fractionation) is needed.

\section{HERBAL THERAPY WITH GYANURA PROCUMBENS LEAVE}

Herbal therapy with GP leave can be divided into two approaches, oral administration and topical or external therapeutic application. In most cases, GP leave is used as single ingredient. But, polyherbal preparation is also possible.

\section{Oral administration}

Various preparations can be made for oral administration. GP leave can be administrated as

a. Tea or herbal drink when its fresh leaves are boiled with water. ${ }^{7}$ Oral administration of aqueous extracts of GP can be orally administered to spontaneously hypertensive due to its antihypertensive effects. Aqueous extracts like tea of GP leave can be orally administered to hypertensive people.

b. Dried leave powders that pored with hot water before drink it Another possibility is to put the powder in the capsule that can be swallowed directly.

c. Herbal extract containing tablet or capsule, and 
d. Food ingredient of functional food that may be used for daily consumption along with the food. ${ }^{43}$ Cake or buns, for example, can be enriched by polyphenol rich GP leave. Polyphenol rich plant components may provide additional health benefits in controlling various internal diseases. ${ }^{44}$

\section{Topical or external therapeutic application}

Topical therapy is used to treat chronic pain, rheumatism, topical inflammation, wound healing/traumatic injuries and viral ailments. GP essential oils are potent external therapeutic agent. ${ }^{13,14}$ Various ethanol extract containing topical gel or cream can be produced. ${ }^{15}$

\section{CONCLUSION}

Leaves of Gynura procumbens is good resource for oral or topical herbal medicine/ingredient.

\section{FUTURE RECOMMENDATIONS}

Future recommendations phytochemical studies for bioactive compounds is still needed. Information in this phytochemical profile is still limited. It relatedness with its bioactivities is needed to be continued also. Herbal therapy research.

\section{CONFLICT OF INTEREST}

The authors declare that there is no conflict of interest in writing this review.

\section{ABBREVIATIONS}

GP: Gynura procumbens; COX-2: Cyclooxygenase-2; LPS: Lipopolysaccharides; GPP: Ethannol fractions of GP leaves (\%, v/v); ACE: Angiotensin-converting enzyme; mRNA: messenger RNA; NOAEL: no-observed-adverse-effect-level.

\section{REFERENCES}

1. Tan HL, Chan KG, Pusparajah P, Lee LH, Goh BH. Gynura procumbens: An overview of the Biological Activities. Front Pharmacol. 2016b;7(52):1-14.

2. Hew CS, Gam LH. Proteome analysis of abundant proteins extracted from the leaf of Gynura procumbens (Lour.) Merr. Appl Biochem Biotechnol. 2011;165(78):1577-86.

3. Algariri K, Atangwho IJ, Meng KY, Asmawi MZ, Sadikun A, Murugaiyah V. Antihyperglycaemic and toxicological evaluations of extract and fractions of Gynura procumbens leaves. Trop Life Sci Res. 2014;25(1):75-93.

4. Algariri K, Meng KY, Atangwho IJ, Asmawi MZ, Sadikun A, Murugaiyah V, et al. Hypoglycemic and anti-hyperglycemic study of Gynura procumbens leaf extracts. Asian Pac J Trop Biomed. 2013;3(5):358-66.

5. Li J, Qin $Y, Y u$, Xiong $Z$, Zheng $L$, Sun $Y$, et al. In vitro simulated digestion and in vivo metabolism of chlorogenic acid dimer from Gynura procumbens (Lour.) Merr.: enhanced antioxidant activity and different metabolites of blood and urine. J Food Biochem. 2019;43(6):e12654

6. Li XJ, Mu YM, Li TT, Yang YL, Zhang MT, Li YS, et al. Gynura procumbens reverses acute and chronic ethanol-induced liver steatosis through MAPK/ SREBP-1C-dependent and -independent Pathways. J Agric Food Chem. 2015;63(38):8460-71

7. Liu M, He M, Gao H, Guo S, Jia J, Ouyang H, et al. Strategy for rapid screening of antioxidant and anti-inflammatory active ingredients in Gynura procumbens (Lour.) Merr. based on UHPLC-Q-TOF-MS/MS and characteristic ion filtration. Biomed Chromatogr. 2019;33(11):e4635.

8. Murugesu K, Murugaiyah V, Saghir SAM, Asmawi MZ, Sadikun A. Caffeoylquinic acids rich versus poor fractions of Gynura procumbens: Their comparative antihyperlipidemic and antioxidant potential. Curr Pharm Biotechnol. 2017;18(4):1132-40.

9. Sunarwidhi AL, Sudarsono S, Nugroho AE. Hypoglycemic effect of combination of Azadirachta indica A. juss. and Gynura procumbens (Lour.) Merr. ethanolic extracts standardized by rutin and quercetin in alloxan-induced hyperglycemic rats. Adv Pharm Bull. 2014;4(2):613-8.

10. Kaewseejan N, Siriamornpun S. Bioactive components and properties of ethanolic extract and its fractions from Gynura procumbens Leaves. Ind Crops Prod. 2015;74:271-8.

11. Akowuah G, Sadikun A, Mariam A. Flavonoid identification and hypoglycaemic studies of the butanol fraction from Gynura procumbens. Pharm Biol. 2002;40(6):405-10.

12. Rosidah YM, Sadikun A, Asmawi M. Antioxidant potential of Gynura procumbens. Pharm Biol. 2008;46(9):616-25.

13. Huang XL, Li XJ, Qin QF, Li YS, Zhang WK, Tang HB. Anti-inflammatory and antinociceptive effects of active ingredients in the essential oils from Gynura procumbens, A Traditional Medicine and A New and Popular Food Material. J Ethnopharmacol. 2019;239:111916.

14. Iskander MN, SongY, Coupar IM, JiratchariyakulW. Anti-inflammatory screening of the medicinal plant Gynura procumbens. Plant Foods Hum Nutr. 2002;57(34):233-44.

15. Jarikasem S, Charuwichitratana S, Siritantikorn S, Chantratita W, Iskander M, Frahm AW, et al. Antiherpetic effects of Gynura procumbens. Evid Based Complement Alternat Med. 2013;394865.

16. Sadikun A, Aminah I, Ismail N, Ibrahim P. Sterols and sterol glycosides from the leaves of Gynura procumbens. Nat Prod. 1996;2(1):19-23.

17. Li JE, Wang WJ, Zheng GD, Li LY. Physicochemical properties and antioxidant activities of polysaccharides from Gynura procumbens leaves by fractional precipitation. Int J Biol Macromol. 2017;95:719-24.

18. Hew CS, Khoo BY, Gam LH. The anti-cancer property of proteins extracted from Gynura procumbens (Lour.) Merr Plos One. 2013;8(7):e68524.

19. Hoe SZ, Kamaruddin MY, Lam SK. Inhibition of Angiotensin-converting enzyme activity by a partially purified fraction of Gynura procumbens in spontaneously hypertensive rats. Med Princ Pract. 2007;16(3):203-8.

20. Krishnan V, Ahmad S, Mahmood M. Antioxidant potential in different parts and callus of Gynura procumbens and different parts of Gynura bicolor. Biomed Res Int. 2015;147909.

21. Hassan Z, Yam MF, Ahmad M, Yusof AP. Antidiabetic properties and mechanism of action of Gynura procumbens water extract in streptozotocin-induced diabetic rats. Molecules. 2010;15(12):9008-23.

22. Zhang XF, Tan BK. Effects of An Ethanolic Extract of Gynura procumbens on serum glucose, cholesterol and triglyceride levels in normal and streptozotocininduced diabetic rats. Singapore Med J. 2000;41(1):9-13.

23. Choi SI, Lee HA, Han JS. Gynura procumbens extract improves insulin sensitivity and suppresses hepatic gluconeogenesis in C57BL/KsJ-db/db mice. Nutr Res Pract. 2016a;10(5):507-15.

24. Choi SI, Park MH, Han JS. Gynura procumbens extract alleviates postprandial hyperglycemia in diabetic mice. Prev Nutr Food Sci. 2016b;21(3):181-6.

25. Kim MJ, Lee HJ, Wiryowidagdo S, Kim HK. Antihypertensive effects of Gynura procumbens extract in spontaneously hypertensive rats. J Med Food. 2006;9(4):587-90.

26. Ng HK, Poh TF, Lam SK, Hoe SZ. Potassium channel openers and prostacyclin play a crucial role in mediating the vasorelaxant activity of Gynura procumbens. BMC Complement Altern Med. 2013;13(1):1-11.

27. Poh TF, Ng HK, Hoe SZ, Lam SK. Gynura procumbens causes vasodilation by inhibiting Angiotensin $\mathrm{II}$ and enhancing bradykinin actions. J Cardiovasc Pharmacol. 2013;61(5)378-84.

28. Abrika OS, Yam MF, Asmawi MZ, Sadikun A, Dieng H, Hussain EA. Effects of extracts and fractions of Gynura procumbens on rat atrial contraction. $J$ Acupunct Meridian Stud. 2013;6(4):199-207.

29. Hoe SZ, Lee CN, Mok SL, Kamaruddin MY, Lam SK. Gynura procumbens Merr. decreases blood pressure in rats by vasodilatation via inhibition of calcium channels. Clinics. 2011;66(1):143-50

30. Wang H, Zhou JW, Fu DH, Zhou Y, Cheng WZ, Liu ZL. Gynura procumbens ethanolic extract suppresses osteosarcoma cell proliferation and metastasis in vitro. Oncol Lett. 2013;6(1):113-7.

31. Nisa F, Hermawan A, Murwanti R, Meiyanto E. Antiproliferative effect of Gynura procumbens (Lour.) Merr. leaves etanolic extract on 7,12-dimethylbenz(a) antracene induced male rat liver. Adv Pharm Bull. 2012;2(1):99-106

32. Shwter AN, Abdullah NA, Alshawsh MA, Alsalahi A, Hajrezaei M, Almaqrami AA, et al. Chemoprevention of colonic aberrant crypt foci by Gynura procumbens in rats. J Ethnopharmacol. 2014;151(3):1194-201.

33. Liew SY, Stanbridge EJ, Yusoff K, Shafee N. Hypoxia affects cellular responses to plant extracts. J Ethnopharmacol. 2012;144(2):453-6.

34. Kamaruzaman KA, Aizat WM, Mat Noor M. Gynura procumbens improved fertility of diabetic rats: preliminary study of sperm proteomic. Evid Based Complement Alternat Med. 2018;9201539

35. Lokhande A, Ingale SL, Lee SH, Sen S, Khong C, Chae BJ, et al. Effects of dietary supplementation with Gynura procumbens (Merr.) on egg yolk cholesterol, excreta microflora and laying hen performance. Br Poult Sci. 2014;55(4):524-31.

36. Zhao P, Li H, Lei Y, LiT, Kim S, Kim I. Effect of fermented medicinal plants on growth performance, nutrient digestibility, fecal noxious gas emissions and diarrhea score in Weanling pigs. J Sci Food Agric. 2016;96(4):1269-74.

37. Mahmood AA, Mariod AA, Al-Bayaty F, Abdel-Wahab SI. Anti-ulcerogenic activity of Gynura procumbens leaf extract against experimentally-induced gastric lesions in rats. J Med Plants Res. 2010;4(8):685-91.

38. Kim J, Lee CW, Kim EK, Lee SJ, Park NH, Kim HS, et al. Inhibition effect of Gynura procumbens extract on UV-B-induced matrix-metalloproteinase 
expression in human dermal fibroblasts. J Ethnopharmacol. 2011;137(1):42733.

39. Iqbal Z, Bello I, Asmawi MZ, Al-mansoub MA, AhmadA, Jabeen Q, et al Vasorelaxant activities and the underlying pharmacological mechanisms of Gynura procumbens Merr. leaf extracts on rat thoracic aorta. Inflammopharmacology. 2019;27(2):421-31.

40. Lee HJ, Lee BC, Chung JH, Wiryowidagdo S, Chun W, Kim SS, et al. Inhibitory effects of an aqueous extract of Gynura procumbens on human mesangial cell proliferation. Korean J Physiol Pharmacol. 2007;11(4):145-8.

41. Yam MF, Sadikun A, Ahmad M, Akowuah GA, Asmawi MZ. Toxicology evaluation of standardized methanol extract of Gynura procumbens. J Ethnopharmacol. 2009;123(2):244-9.

42. Ibrahim MH, Chee KY, Mohd ZNA. Effect of cadmium and copper exposure on growth, secondary metabolites and antioxidant activity in the medicinal plant sambung nyawa (Gynura procumbens (Lour.) Merr). Molecules. 2017;22(10):1 16.

43. Arulselvan P, Ghofar HAA, Karthivashan G, Halim MFA, Ghafar MSA, Fakuraz S. Antidiabetic therapeutics from natural source: A systematic review. Biomed. 2014;4(4):607-17.

44. Yoon NR, Yoon S, Lee SM. Rice cakes containing dietary fiber supplemented with or without artemisia annua and Gynura procumbens Merr. alleviated the risk factors of metabolic syndrome. Clin Nutr Res. 2016;5(2):79-88.

45. Husni Z, Ismail S, Zulkiffli MH, Afandi A, Haron M. In vitro inhibitory effects of Andrographis paniculata, Gynura procumbens, Ficus deltoidea and Curcuma xanthorrhiza extracts and constituents on human liver glucuronidation activity. Pharmacogn Mag. 2017;13(2):s236-43.

Article History: Submission Date : 09-04-2020; Revised Date : 05-06-2020; Acceptance Date : 22-07-2020

Cite this article: Timotius KH, Rahayu I. Overview of Herbal Therapy with Leave of Gynura procumbens (Lour.) Merr. J Young Pharm. 2020;12(3):201-6. 